\title{
The Economic Burden of Cancer in Spain: A Literature Review
}

\section{Paula Andrade, Jose A Sacristan and Tatiana Dilla*}

Lilly Espana, Avenida de la Industria, 28108 Alcobendas, Madrid, Spain

\begin{abstract}
Although cancer is known to impose a huge financial burden, a comprehensive review summarising the information available on the burden of cancer in Spain has not yet been published. The objective of this study was to conduct a descriptive review of the literature on cost of illness studies of cancer in Spain over the past 15 years to better understand the socioeconomic burden of the disease and better allocate resources and research funds. 27 articles were identified relative to healthcare costs attributable to prostate, breast, colorectal, lung, cervical, skin cancer, and soft tissue sarcoma. The majority of studies underestimated total costs, focusing just on direct costs. Additionally, cancer costs vary widely across studies as a result of the lack of a methodological consensus to estimate them. However, despite the variation in the costs reported, this updated literature synthesis demonstrated that cancer represents an important economic burden.
\end{abstract}

Keywords: Cost-of-illness; Cancer; Economic burden; Systematic review; Oncology

\section{Introduction}

Cancer is the second leading cause of death in the European Union (EU) after diseases of the circulatory system [1]. In 2012, the estimated number of new cases of cancer was 3.4 million (1.8 million occurring in men, 1.6 million occurring in women) and 1.75 million people (976,000 men, 779,000 women) died from cancer in the EU member states [2]. Estimates of incidence in Spain from the most recent studies range from 208,000 to 215,500 new cancer cases, and the number of total cancer deaths was estimated at approximately 102,700 [2,3]. When focusing on different cancer sites, prostate, lung and colorectal were the most common cancers among men. Breast cancer was the most common cancer in women, followed by colorectal and corpus uteri cancers. However, the ranking of cancers by frequency of death differed from the ranking for incidence. Lung cancer was the most frequent cause of death from cancer in men, followed by colorectal cancer and prostate cancers, while breast cancer was the leading cause of death in women, followed by colorectal and lung cancers. Overall, the cancer burden profile throughout Spain is similar to that in Europe [2]. Thus, cancers of the lung, colorectal, breast in women, and prostate in men accounted for nearly half of all new cases [3].

Because of the high incidence and mortality rates, the costs of cancer to the health care system and to the society are substantial, in the addition to the impact it has on patients and their families [4]. A recent study of the economic burden of cancer in EU countries, estimated the cost of lung, breast, colorectal and prostate cancers at $€ 55,3$ billion, representing $44 \%$ of the total economic cost of cancer [5]. In Spain, the whole cost of cancer was estimated at 9,016 millions of euros, in the year 2009. Furthermore, these costs are likely to increase further, as more people require treatment and treatments become more expensive [6,7].

Cost-of-Illness (COI) studies measure the overall economic burden or impact of a specific disease, identifying and quantifying all the costs of the disease [8-10]. These studies separates economic burden into disease-attributable direct costs; indirect costs, resulting from the loss of productivity by the patient; and intangible costs, incurred from pain and suffering. Direct costs measure the resources whose consumption is wholly attributable to the use of health care intervention, such as prevention, diagnosis, treatment, rehabilitation and palliative care. The direct costs are also classified into two categories: direct medical costs and direct non-medical costs. Direct medical costs are the easiest to calculate and encompass costs by medical providers, carried by the institutions that provide care. Direct nonmedical costs are imposed on nonmedical care personnel such as patients and their family, including for example the transportation of patient and the costs for taking care of the patient at home. The indirect costs represents the value of decreased or lost productivity that can be the result of disease, premature death, treatment side effects, or time spending receiving treatment. This not only affects the patient but also the family members, who reduce or stop their employment to take care of the patient. The intangible costs are the most difficult to quantify because of the difficulty in rendering concepts related to degrees of pain and anxiety, familiar and social repercussions, loss of quality of life, and are usually excluded from economic evaluations [11].

The identification and measurement of direct and indirect costs of a disease like cancer are complicated, but the information obtained can help in understanding the weight of the disease in terms of the resources consumed and to assess their socio-economic consequences for the society $[9,10]$. Moreover, knowledge of the distribution of costs among its different components would identify areas of inefficiency that enable better allocation of resources and governmental research funds $[9,10]$.

The costs of cancer have been reported in different European countries, such as Germany, the Netherlands, and England [5]. However, few studies have estimated the economic burden of cancer in Spain and most of these reports have performed analyses considering only one type of cancer or costs. Therefore, the aim of the present article was to review and summarize the data from the existing cost of illness studies over the past 15 years regarding the healthcare costs attributable to cancer in Spain. We consider that to have this type of information relative to the different types of cancer could be useful to

*Corresponding author: Tatiana Dilla, Lilly Espana, Avenida de la Industria, 30 28108 Alcobendas, Madrid, Spain, Tel: +34 916635334; Fax: +34 916635231 E-mail: dilla_tatiana@lilly.com

Received December 16, 2016; Accepted February 01, 2017; Published February 07, 2017

Citation: Andrade P, Sacristan JA, Dilla T (2017) The Economic Burden of Cancer in Spain: A Literature Review. Health Econ Outcome Res Open Access 3: 125. doi: 10.4172/2471-268x/1000125

Copyright: (c) 2017 Andrade P, et al. This is an open-access article distributed under the terms of the Creative Commons Attribution License, which permits unrestricted use, distribution, and reproduction in any medium, provided the original author and source are credited. 
better understand the relative socioeconomic burden of the different diseases and be crucial to better allocate public resources and research funds. At the same time, the results of the review will allow identifying those areas where information is scarce and, therefore, more studies are needed.

\section{Methods}

A descriptive review was performed to identify studies conducted in Spain reporting the costs related to the different types of cancer. The literature search terms and key words were developed to capture studies providing information on direct and indirect costs regarding all cancer types. The search was performed in EMBASE and MEDLINE electronic databases covering articles published in the last 15 years (from 1998 to 2015) in English or Spanish languages. The detailed electronic search strategy is displayed in the additional file (Appendix 1). For the hand search, the reference list of all included citations was reviewed to recover additional articles not identified in the electronic search. For every study we extracted information on the study design, date of the study, date of the reported costs, follow-up duration, total sample size, type of cost and the value. We excluded economic evaluations focused on some on specific drug treatments, or cost-effectiveness, cost-utility, cost-minimization studies.

\section{Results}

The main characteristics of the 27 studies included in our review are summarized in Table 1. Collectively, the studies reviewed reported costs for the following cancer types: prostate cancer [11-15], breast cancer [12,16-21], colorectal cancer [22-25], lung cancer [12,26-29], cervical cancer [16,30-33], skin cancer [34-37] and soft tissue sarcoma [38]. The majority of these studies focused on direct costs, such as diagnostic, treatment and hospitalization costs; while only four of them assessed indirect costs. Three of the studies quantifying indirect costs concentrated on temporal disability costs, and one study assessed also the costs derived from permanent disability and premature death. Of the 27 studies, 14 had an observational design (retrospective, crosssectional or prospective) and the rest of them were cost estimation studies using data from different medical databases or from an expert consensus process. The follow-up periods ranged from four weeks to five years, although it was not specified in the majority of cases.

Because of the considerable design differences among included studies and the heterogeneity of reported outcomes, no attempt has been made to pool results of different studies. Thus, direct and indirect costs were described separately for every type of cancer presented.

\section{Costs of prostate cancer}

Prostate cancer is the most frequently diagnosed cancer among men in Spain, with 27,850 incident cases in 2012 [2,39]. The incidence has increased over the last decades, partly due to the more frequent use of diagnostic tools and needle biopsies in asymptomatic men [40,41]. In 2012, the estimated mortality associated with prostate cancer was 5,481 in Spain, making it the third leading cause of death due to cancer for men [1,39]. Therefore, the economic burden of prostate cancer is one of the largest among malignant tumours due to the high incidence of the disease and increasing survival rates [42]. Although less than 5\% of patients are in the metastatic stage at their initial diagnosis, up to $40 \%$ of patients diagnosed with localized prostate cancer will develop metastatic disease after undergoing local therapy with curative intent [43].

The four studies selected of prostate cancer costs in this review estimated only direct costs [12-15]. One study quantified medical costs associated with localized prostate cancer [14] and two studies took into account men who had advanced prostate cancer $[12,15]$. A fourth study evaluated treatment costs of prostate cancer patients in the first year after diagnosis [13].

As we have already mentioned in previous sections, Pockett et al. [12] evaluated the hospital burden associated with metastatic disease. Of the total of the 7,546 patients with prostate cancer, $16.3 \%$ were admitted due to Metastatic Bone Disease (MBD). Of these patients, $15.0 \%$ later developed Skeletal-Related Events (SRE) requiring hospital admission. With regard to costs, they reported that mean hospitalization costs with cancer only were $€ 3,194$; and for the first hospital admission due to MBD and SRE the average costs increased to $€ 3,180$ and $€ 3,585$, respectively.

Fourcade et al. [13] evaluated the direct costs in relation to initial diagnosis and treatment (with surgery, radio-chemo-and hormonal therapy) in prostate cancer patients, using drug costs from 2006. The mean costs per patient for initial treatment were $€ 3,256$. Surgery was the major cost driver $(€ 1,151)$, followed by hormonal therapy $(€ 1,053)$, radiotherapy (€617) and chemotherapy (€119). The total costs in the first year after diagnoses were $€ 114.6$ million. When evaluating costs of prostate cancer by stage they found that costs of diagnosis and initial treatment of stage II patients were the highest, followed by stage I, while the initial treatment of stage IV patients cost less than any other stage. These differences were related to the lower frequency of surgery in stage III and IV than stage I and II. Almost in the same period of time, Becerra et al. [14] calculated direct costs of treatment in 398 patients recruited between 2003 and 2005 with localized prostate cancer. The median costs of treatments were $€ 3,229, € 5,369$ and $€ 6,265$, for the groups of patients treated with external 3D conformal radiotherapy, brachytherapy and radical retro pubic prostatectomy $(\mathrm{RP})$, respectively.

Hart et al. [15] estimated in a recent study the lifetime costs attributable to advanced prostate cancer at $€ 19,961$ per patient, with a mean survival time of 8.4 years. In addition, study results indicated that the total cost for 2012 incident cases was $€ 61$ million.

\section{Costs of breast cancer}

Breast cancer is a major public health problem in developed countries, not only in terms of frequency but also mortality. In Spain it is the most common neoplastic disease and is the main cause of death from cancer in women, with an estimated rates of 25,200 incident cases and 6,075 reported deaths, in 2012 [2,39]. The progressive ageing of the population, the existence of screening programmes, and the appearance of more and better treatments have contributed to the increased rate observed in recent years.

A total of seven studies evaluating the cost for breast cancer in women were selected for this review [12,16-21]. Five of them assessed direct costs and two quantified the indirect cost in terms of loss productivity.

Oliva et al. [16] estimated the productivity loss caused by mortality and morbidity in breast cancer patients. The annual costs estimated for the year 2003 reached $€ 288.7$ million, by the traditional human capital (HC) approach. However, by the friction cost (FC) approach, indirect costs varied significantly, being $€ 11.6$ million. According the $\mathrm{HC}$ method, permanent disability was the main cause of productivity loss, followed by early mortality. By the FC approach, indirect costs caused by permanent disability were higher than the other two factors (temporary disability and premature mortality). 
Citation: Andrade P, Sacristan JA, Dilla T (2017) The Economic Burden of Cancer in Spain: A Literature Review. Health Econ Outcome Res Open Access 3: 125. doi: 10.4172/2471-268x/1000125

Page 3 of 8

\begin{tabular}{|c|c|c|c|c|c|c|c|}
\hline Reference & Type of tumour & Study design & $\begin{array}{l}\text { Year of } \\
\text { reported } \\
\text { costs }\end{array}$ & Follow-up & $\begin{array}{l}\text { Sample } \\
\text { size }\end{array}$ & Parameter & Reported cost \\
\hline Pockett et al. [12] & $\begin{array}{c}\text { Breast cancer, lung } \\
\text { cancer and prostate } \\
\text { cancer with bone } \\
\text { metastases }\end{array}$ & $\begin{array}{l}\text { Hospital burden analysis } \\
\text { across Spain using } \\
\text { hospital activity database } \\
\text { which collects inpatient } \\
\text { episode data for Spain }\end{array}$ & 2003 & 3 years & 28,162 & $\begin{array}{l}\text { DC: hospital admission } \\
\text { (mean cost per patient) }\end{array}$ & $\begin{array}{c}\text { Index admission for cancer only: } \\
€ 2,374(\mathrm{BC}), € 4,994 \text { (LC) and } \\
€ 3,194 \text { (PCa) } \\
\text { Admission with bone metastasis: } \\
€ 3,515 \text { (BC), } € 4,227 \text { (LC) and } \\
€ 3,180 \text { (PCa) } \\
\text { Admission with a skeletal-related } \\
\text { event: } € 3,757(\mathrm{BC}), € 4,298 \text { (LC) } \\
\text { and } € 3,585 \text { (PCa) }\end{array}$ \\
\hline Fourcade et al. [13] & Prostate cancer & $\begin{array}{l}\text { Cost estimation study } \\
\text { collecting data from the } \\
\text { Information Management } \\
\text { Systems, Inc. database, } \\
\text { survival data, expert } \\
\text { opinion, published data } \\
\text { and unit costs from official } \\
\text { sources }\end{array}$ & 2006 & 1 year & 2474 & $\begin{array}{c}\text { DC: diagnostic and } \\
\text { treatment } \\
\text { (mean cost per patient) }\end{array}$ & $€ 3,337.6$ \\
\hline Becerra et al. [14] & $\begin{array}{l}\text { Localized prostate } \\
\text { cancer }\end{array}$ & $\begin{array}{c}\text { Prospective cost } \\
\text { comparison study in } \\
\text { Catalonia }\end{array}$ & $2003-2005$ & 6 months & 398 & $\begin{array}{c}\text { DC: treatment } \\
\text { (mean cost per patient) }\end{array}$ & $\begin{array}{c}€ 3,229 \text { (radical prostatectomy) } \\
€ 5,369 \text { (prostate brachytherapy) } \\
€ 6,265 \text { (external 3D conformal } \\
\text { radiotherapy) }\end{array}$ \\
\hline Hart et al. [15] & $\begin{array}{c}\text { Advanced prostate } \\
\text { cancer }\end{array}$ & $\begin{array}{l}\text { Economic model with } \\
\text { Spanish incidence, } \\
\text { mortality, and cost data }\end{array}$ & 2012 & Lifetime & 3,047 & $\begin{array}{l}\text { DC: treatment and } \\
\text { follow-up } \\
\text { (mean cost per patient) }\end{array}$ & $€ 19,961$ \\
\hline Oliva et al. [16] & $\begin{array}{c}\text { Cervical and breast } \\
\text { cancer }\end{array}$ & $\begin{array}{l}\text { Cost estimation study on } \\
\text { productivity loss using the } \\
\text { traditional human capital } \\
\text { (HC) and friction cost (FC) } \\
\text { method }\end{array}$ & 2000 & $\begin{array}{c}\text { Not } \\
\text { specified }\end{array}$ & $\begin{array}{c}\text { Not } \\
\text { specified }\end{array}$ & $\begin{array}{l}\text { IC: total premature } \\
\text { mortality, permanent } \\
\text { disability and temporary } \\
\text { disability costs (total } \\
\text { cost) }\end{array}$ & $\begin{array}{l}\text { Traditional human capital }(\mathrm{HC}) \text { : } \\
€ 43.4(\mathrm{CV}) \text { and } 288.7(\mathrm{BC}) \\
\text { Friction cost }(\mathrm{FC}): € 1.1 \text { million } \\
(\mathrm{CV}) \text { and } € 11.6 \text { million }(\mathrm{BC})\end{array}$ \\
\hline GEDEFO [17] & Breast cancer & $\begin{array}{l}\text { Cross-sectional study in } \\
110 \text { Spanish centres }\end{array}$ & 2004 & $\begin{array}{c}\text { Not } \\
\text { specified }\end{array}$ & 1,886 & $\begin{array}{c}\text { DC: treatment } \\
\text { (mean cost per patient) }\end{array}$ & $€ 428.5$ per cycle per patient \\
\hline $\begin{array}{c}\text { Vicente-Herrero et } \\
\text { al. [18] }\end{array}$ & Breast cancer & $\begin{array}{l}\text { Cost estimation study } \\
\text { based on the minimum } \\
\text { standards linked to the } \\
\text { cost-day according three } \\
\text { methods }\end{array}$ & 2010 & $\begin{array}{c}\text { Not } \\
\text { specified }\end{array}$ & 2,751 & IC: temporal disability & $9.956 .817 €$ to $€ 14.767 .860$ \\
\hline $\begin{array}{l}\text { Angulo-Pueyo et } \\
\text { al. [19] }\end{array}$ & Breast cancer & $\begin{array}{l}\text { Observational study in } 199 \\
\text { Spanish healthcare areas }\end{array}$ & 2008-2009 & $\begin{array}{c}\text { Not } \\
\text { specified }\end{array}$ & 45,593 & $\begin{array}{c}\text { DC: surgery } \\
\text { (mean cost per patient) }\end{array}$ & $\begin{array}{c}€ 7,078-€ 9,036 \text { (conservative } \\
\text { surgery) } \\
€ 6,161-€ 8,526 \text { (non-conservative } \\
\text { surgery) }\end{array}$ \\
\hline Arrospide et al. [20] & Breast cancer & $\begin{array}{l}\text { Economic model based on } \\
\text { micro-costing technique }\end{array}$ & 2011 & 5 years & $\begin{array}{c}\text { Not } \\
\text { specified }\end{array}$ & $\begin{array}{c}\text { DC: diagnostic and } \\
\text { treatment } \\
\text { (mean cost per patient) }\end{array}$ & $\begin{array}{c}€ 9,838 \text { (stage 0) to } € 28,776 \\
\text { (stage III) }\end{array}$ \\
\hline \multirow[t]{2}{*}{$\begin{array}{l}\text { Jódar-Sánchez et } \\
\text { al. [21] }\end{array}$} & Early breast cancer & $\begin{array}{l}\text { Descriptive cost analysis } \\
\text { of six radiation therapy } \\
\text { techniques by an expert } \\
\text { committee }\end{array}$ & 2013 & $\begin{array}{c}\text { Not } \\
\text { specified }\end{array}$ & $\begin{array}{c}\text { Not } \\
\text { specified }\end{array}$ & $\begin{array}{l}\text { DC: treatment } \\
\text { (total cost) }\end{array}$ & $\begin{array}{c}€ 4.066 \text { (3DCRT) to } € 7.715 \\
\text { (IORT) }\end{array}$ \\
\hline & Colorectal cancer & $\begin{array}{l}\text { Prospective, observational } \\
\text { and unicentric study }\end{array}$ & 2003 & $\begin{array}{c}\text { Not } \\
\text { specified }\end{array}$ & 59 & $\begin{array}{l}\text { DC: diagnostic process } \\
\text { including primary care } \\
\text { visits and hospital } \\
\text { assistance } \\
\text { (mean cost per patient) }\end{array}$ & $8,137,7 €$ \\
\hline Novoa et al. [22] & Colorectal cancer & $\begin{array}{l}\text { Retrospective } \\
\text { observational study in } \\
\text { Catalan hospitals }\end{array}$ & 2000 & 5 years & $\begin{array}{c}\text { Not } \\
\text { specified }\end{array}$ & $\begin{array}{c}\text { DC: treatment } \\
\text { (mean cost per patient) }\end{array}$ & $€ 27,000$ \\
\hline Cots et al. [23] & Colorectal cancer & $\begin{array}{l}\text { Descriptive study using the } \\
\text { Spanish minimum wage } \\
\text { (SMW) as reference }\end{array}$ & 2011 & 1 year & $\begin{array}{c}\text { Not } \\
\text { specified }\end{array}$ & $\begin{array}{l}\text { IC: temporal disability } \\
\text { (total cost) }\end{array}$ & $4.335,521,92 €$ \\
\hline $\begin{array}{l}\text { Vicente-Herrero et } \\
\text { al. [24] }\end{array}$ & $\begin{array}{c}\text { Metastatic } \\
\text { colorectal cancer }\end{array}$ & $\begin{array}{l}\text { Prospective, observational } \\
\text { and unicentric study }\end{array}$ & 2012 & 23 months & 157 & $\begin{array}{c}\text { DC: treatment } \\
\text { (mean cost per patient) }\end{array}$ & $€ 20.478,67$ \\
\hline Torres et al. [25] & Lung cancer & $\begin{array}{l}\text { Prospective, observational } \\
\text { and unicentric study }\end{array}$ & 2003 & $\begin{array}{c}\text { Not } \\
\text { specified }\end{array}$ & 160 & $\begin{array}{c}\text { DC: diagnostic } \\
\text { (mean cost per patient) }\end{array}$ & $\begin{array}{l}€ 5,070 \text { (NSCLC) } \\
€ 3,692 \text { (SCLC) }\end{array}$ \\
\hline Arca et al. [26] & $\begin{array}{c}\text { Advanced or } \\
\text { metastatic NSCLC }\end{array}$ & $\begin{array}{l}\text { Cost estimation study } \\
\text { using Delphi method }\end{array}$ & 2009 & Lifetime & $\begin{array}{c}\text { Not } \\
\text { specified }\end{array}$ & $\begin{array}{c}\text { DC: medication } \\
\text { (mean cost per patient) }\end{array}$ & $€ 11,301$ to $€ 32.754$ \\
\hline Isla et al. [27] & $\begin{array}{l}\text { Lung cancer and } \\
\text { bladder cancer }\end{array}$ & $\begin{array}{l}\text { Cost estimation study of } \\
\text { cancer attributable to work. } \\
\text { Medical costs were derived } \\
\text { from the National Health } \\
\text { System cost accounts }\end{array}$ & 2008 & $\begin{array}{c}\text { Not } \\
\text { specified }\end{array}$ & 10,652 & $\begin{array}{l}\text { DC: treatment } \\
\text { (total cost) }\end{array}$ & $\begin{array}{c}€ 61.2 \text { million lung cancer } \\
€ 26.5 \text { million bladder cancer }\end{array}$ \\
\hline
\end{tabular}




\begin{tabular}{|c|c|c|c|c|c|c|c|}
\hline Garcia et al. [28] & Lung cancer & $\begin{array}{c}\text { Retrospective } \\
\text { observational study in } 9 \\
\text { hospitals in Catalonia }\end{array}$ & 2008 & 3 years & 232 & $\begin{array}{c}\text { DC: diagnostic and } \\
\text { treatment (CTx, RT, } \\
\text { other inpatient care, and } \\
\text { cost of continuing care) } \\
\text { (mean cost per patient) }\end{array}$ & $\begin{array}{l}€ 13,218 \text { to } € 16,120 \text { (NSCLC) } \\
€ 12,482 \text { to } € 15,418 \text { (SCLC) }\end{array}$ \\
\hline Corral et al. [29] & Cervical cancer & $\begin{array}{l}\text { Retrospective, } \\
\text { observational and } \\
\text { multicentre study }\end{array}$ & 1999-2002 & $\begin{array}{c}\text { Not } \\
\text { specified }\end{array}$ & 6912 & $\begin{array}{c}\text { DC: treatment } \\
\text { (mean cost per patient) }\end{array}$ & $\begin{array}{c}€ 3,098 \text { (cervical cancer) } \\
€ 2,192 \text { (carcinoma in situ) }\end{array}$ \\
\hline Gil et al. [30] & Cervical cancer & $\begin{array}{l}\text { Retrospective, } \\
\text { observational and } \\
\text { unicentric study }\end{array}$ & 1999-2002 & $\begin{array}{c}\text { Not } \\
\text { specified }\end{array}$ & 667 & $\begin{array}{c}\text { DC: treatment } \\
\text { (mean cost per patient) }\end{array}$ & $€ 5,247$ \\
\hline $\begin{array}{c}\text { De Juanes et al. } \\
\text { [31] }\end{array}$ & Cervical cancer & $\begin{array}{l}\text { Retrospective, } \\
\text { observational and } \\
\text { multicentre study }\end{array}$ & 2010 & 2 years & 849 & $\begin{array}{l}\text { DC: diagnostic and } \\
\text { treatment } \\
\text { (total) }\end{array}$ & $\begin{array}{c}€ 912.43 \text { to } € 6,261.30 \text { (according } \\
\text { to cytology result) } \\
€ 790.10 \text { to } 7,041.70 \text { (according } \\
\text { to histology grade) }\end{array}$ \\
\hline Blade et al. [32] & Cervical cancer & $\begin{array}{l}\text { Cross sectional study in } \\
\text { women who attended } \\
\text { screening for CC in } \\
\text { Cantabria }\end{array}$ & 2011 & $\begin{array}{c}\text { Not } \\
\text { specified }\end{array}$ & 189,111 & $\begin{array}{c}\text { DC and IC } \\
\text { (total annual costs) }\end{array}$ & $\begin{array}{c}€ 567.567 \text { (direct costs) } \\
€ 386,122.02 \text { (indirect costs) }\end{array}$ \\
\hline $\begin{array}{l}\text { Garcia-Garrido et } \\
\text { al. [33] }\end{array}$ & $\begin{array}{c}\text { Non-melanoma skin } \\
\text { cancer }\end{array}$ & Database analysis & 2005 & $\begin{array}{c}\text { Not } \\
\text { specified }\end{array}$ & $\begin{array}{c}\text { Not } \\
\text { specified }\end{array}$ & $\begin{array}{c}\text { DC: treatment } \\
\text { (mean cost per episode) }\end{array}$ & $€ 273.71$ to $€ 1,129.84$ \\
\hline $\begin{array}{l}\text { Hernández-Martin } \\
\text { et al. [34] }\end{array}$ & $\begin{array}{c}\text { Non-melanoma skin } \\
\text { cancer }\end{array}$ & $\begin{array}{l}\text { Costs analysis using the } \\
\text { activity-based costing } \\
\text { method }\end{array}$ & 2006-2010 & 4 years & $\begin{array}{c}\text { Not } \\
\text { specified }\end{array}$ & $\begin{array}{l}\text { DC: treatment } \\
\text { (mean cost per patient } \\
\text { and total cost) }\end{array}$ & $\begin{array}{c}€ 3,398,540 \text { total costs } \\
€ 2,238 \text { per patient }\end{array}$ \\
\hline $\begin{array}{l}\text { Aguilar-Bernier et } \\
\text { al. [35] }\end{array}$ & $\begin{array}{l}\text { Cutaneous } \\
\text { melanoma }\end{array}$ & $\begin{array}{c}\text { Descriptive study based on } \\
\text { theoretical model }\end{array}$ & 2007 & $\begin{array}{c}\text { Not } \\
\text { specified }\end{array}$ & $\begin{array}{c}\text { Not } \\
\text { specified }\end{array}$ & $\begin{array}{c}\text { DC: diagnostic, } \\
\text { treatment and follow-up } \\
\text { (mean cost per patient) }\end{array}$ & $\begin{array}{c}\text { From } € 2,066.68 \text { to } 9,082.79 \\
\text { in patients with lymph node } \\
\text { metastasis }\end{array}$ \\
\hline $\begin{array}{c}\text { Fernandez et al. } \\
{[36]}\end{array}$ & $\begin{array}{l}\text { Cutaneous } \\
\text { melanoma }\end{array}$ & $\begin{array}{l}\text { Prospective observational } \\
\text { study }\end{array}$ & 2013 & $\begin{array}{c}\text { Not } \\
\text { specified }\end{array}$ & 100 & $\begin{array}{l}\text { DC: biopsy } \\
\text { (total cost) }\end{array}$ & $€ 9,486.57$ to $€ 10,471.2$ \\
\hline Menchon et al. [37] & Soft tissue sarcoma & $\begin{array}{c}\text { Retrospective } \\
\text { observational study }\end{array}$ & 2009-2011 & $\begin{array}{c}\text { Not } \\
\text { specified }\end{array}$ & 48 & $\begin{array}{c}\text { DC: diagnostic and } \\
\text { treatment } \\
\text { (mean cost per patient) }\end{array}$ & $€ 14,427.58$ \\
\hline
\end{tabular}

BC: Breast Cancer; CTx: Chemotherapy Treatment; RT: Rradiation Therapy; DC: Direct Cost; ID: Indirect Cost; LC: Lung Cancer; PCa: Prostate Cancer

Table 1: Summary table of COI studies of cancer in Spain.

Another study estimated the costs of chemotherapy treatment in women with breast cancer, in 2004 [17]. The mean cost was $€ 428.5$ per patient and per cycle. The group of patients with metastatic disease incurred the greatest cost $(€ 640.4$ per cycle), followed by patients on neoadjuvant treatment ( $€ 232.5$ per cycle) and the patients with adjuvant treatment $(€ 180.1$ per cycle).

In the study of Pockett et al. [12], investigating the hospital burden of disease, found that of the total of 10,090 included patients with breast cancer, $9.5 \%$ were subsequently admitted due to MBD within 3 years. Additionally, $21.1 \%$ of these patients later developed an SRE requiring hospital admission. The average cost of the index admission with cancer only was $€ 2,374$; with the average cost of the first admission with MBD increasing to $€ 3,515$; and $€ 3,757$ for the first admission with a SRE.

Vicente-Herrero et al. [18] assessed the productivity costs for breast cancer. They calculated the number of workdays lost due to Temporal Disability (TD) in 2010. A total of 2,751 TD processes were reported with 567,340 workdays lost, and the mean process duration was 179.87 days per TD process. Malignant neoplasm of breast and carcinoma in situ of breast represented the highest number of processes and the greatest number of workdays lost due to TD. A total cost due to work disability in breast cancer patients was estimated at $€ 9,956,817$; $€ 11,976,547$ and $€ 14,767,860$; according to IPREM (Public Indicator of Multiple Effect Incomes), the SMI (Minimum Wage) and the official data from Spanish Ministry of Labour-2010, respectively.

Angulo-Pueyo et al. [19] compared in a recent study the costs of conservative surgery (CS) plus radiotherapy vs. non-conservative surgery (NCS), during 2008-2009. Costs were calculated indirectly, by using All-Patients Diagnosis Related Groups (AP-DRG) and directly, by using Spanish Network oh Hospital Costs (SNHC) data. Depending on the method used as a reference, the cost of CS was estimated at $€ 7,078$ to $€ 9,036$ and that of NCS was $€ 6,161$ to $€ 8,526$. However, they found CS had lower opportunity costs than NCS when day-case surgery was performed frequently-more than $46 \%$ of cases (following SNHC estimates) or $23 \%$ of cases (following AP-DRG estimates). A third study assessed direct costs related to diagnosis and treatment of breast cancer by stage of disease in Basque Health Services [20]. The initial cost was $€ 9,838$ for stage $0, € 17,273$ for stage $I, € 22,145$ for stage II and $€ 28,776$ for stage III. The follow up annual cost was $€ 172$ for the stage 0 , €908 for stage I, €994 for stage II and €1,166 for stage III. The annual cost for stage IV was $€ 17,879$, resulting in $€ 50,061$ total cost per patient (with a mean duration of 2.8 years). Chemotherapy determines the greatest percentage of breast cancer costs in stage IV patients.

Finally, Jódar-Sánchez et al. [21] quantified the direct healthcare costs at 2013 prices associated with six Radiation Therapy (RT) techniques for the adjuvant treatment of early breast cancer, according to a descriptive analysis performed by a team of radiation oncologists. Treatment costs included hospitalization, medical and nursing consults, radiological examinations and dosimetry calculation. Treatment costs for the 3-dimensional conformal RT (3DCRT) were 6,786 using conventional fractionation and $€ 4,998$ using hypofractionation. For Partial-Breast Irradiation (PBI) costs were $€ 4,066, € 4,797, € 4,376$ and $€ 7,715$ for $3 \mathrm{DCRT}$, low-dose rate brachytherapy, high-dose rate brachytherapy, and intraoperative RT (IORT), respectively.

\section{Costs of colorectal cancer}

Colorectal cancer constitutes a major burden on health care resources, causing substantial morbidity and mortality. Despite its significant treatment advances, colorectal is the most frequent cancer 
type in Spain when the cases in men and women are combined, with 32,240 incident cases; and the second cause of death by cancer, with 14,700 deaths in 2012 [2,39]. The impact of colorectal cancer will increase in the coming years due to an ageing population [44].

Four studies have examined colorectal cancer costs in Spain. Three of the selected studies assessed direct medical costs related to colorectal cancer $[22,23,25]$ and only one study presented indirect costs due to temporal working disability [24].

Novoa et al. [22] assessed the direct costs of diagnostic services, according 2003 prices. Mean total diagnostic process cost per patient was $€ 8,137$, including primary care medical visits and hospital assistance (length of stay, surgical procedure times, administered medication, pathological anatomy and laboratory tests; and complementary explorations) from the first symptoms to diagnosis. The majority of costs were due to hospital care (98.7\%). Stage I patients were the ones who had lower proportion of costs associated with hospitalization and a higher proportion of costs associated with hospital emergency department visits and primary care. This analysis was part of a larger study assessing also the cost of hospital treatment and follow up to 5 years in patients with colorectal cancer [23]. The average cost of treatment during 5 years after cancer diagnosis was $€ 27,000$ per patient.

Only one of the studies included considered the indirect costs [24]. The study assessed the number of workdays lost due to TD in patients with colorectal cancer, during the year 2011. A total of 1,046 TD processes were reported with 202,784 workdays lost, and the mean process duration was 194 days/year. Thus, the resulting cost of the pathology due to TD was 4,335,521 euros. The malignant neoplasia of colon represented the highest number of processes and the greatest number of workdays lost due to TD, in the total processes related to neoplasia of the colon and rectum.

The most up-to-date study examined costs of combinations of chemotherapies and biologics at 2012 prices, which have become the standard of care for metastatic colorectal cancer [24]. FOLFOX (oxaliplatin infusion and 5-fluorouracil/leucovorin) and FOLFIRI (irinotecan 5-fluorouracil/leucovorin) were the most frequent chemotherapy regimens in $1^{\text {st }}$ and $2^{\text {nd }}$ line $(65.0 \%$ and $66.9 \%$, respectively), along with monoclonal antibodies (mAbs) bevacizumab and cetuximab (31.8\% and $28.6 \%$, respectively). The mean treatment cost per patient with metastatic colorectal cancer was $€ 20,478$, with nearly two years of follow-up. The total costs were $€ 8,981$ in $1^{\text {st }}$ line and oxaliplatin-based therapies were incurred with the highest cost. For the $2^{\text {nd }}$ line treatment, the total costs were $€ 9,512$, with the highest cost observed in patients with the FOLFIRI regimen.

\section{Costs of lung cancer}

Lung cancer ranks as the first cause of tumour-related deaths in Europe, with 353,500 deaths in 2012. In Spain, lung cancer is the main cause of death from cancer in men and the third in women. Overall, it is estimated that Spain had a total of 26,715 incident cases and a total of 21,120 deaths in 2012 [2]. The lung cancer morbidity and mortality have a significant economic impact on the healthcare system and society. Non-small-cell lung cancer (NSCLC) is the most prevalent type of lung cancer, occurring in $80-85 \%$ of lung cancer patients [45]. Fifty percent of lung cancer patients present at diagnosis with advanced or metastatic disease.

All the studies selected in this review focused on the assessment of direct costs. Two studies included only patients with advanced or metastatic disease [12,27]. The study carried out by Arca et al. [26] assessed the cost of the diagnosis process in a prospective study in 2003. They found that the mean cost for diagnosing lung cancer was $€ 4,643$. This cost was found to be higher in patients diagnosed with NSCLC $(€ 5,070)$ than in patients with small-cell lung cancer (SCLC) $(€ 3,692)$. At the same time, patients who were diagnosed later with advanced stages of NSCLC incurred higher diagnostic costs. Furthermore, the mean cost for outpatients $(€ 2,503)$ was $62 \%$ lower than that for hospitalization $(€ 6,579)$.

Pockett et al. [12] evaluated the hospital burden of bone metastases (MBD) and skeletal-related events (SRE) in 28,162 patients with lung, breast, and prostate cancers, admitted between January 2003 and December 2003 into a public or private Spanish hospital. It was shown that within 3 years, $15.6 \%$ of lung cancer patients $(n=10,526)$ were subsequently admitted due to MBD. Additionally, $26.0 \%$ of these patients later developed a SRE requiring hospital admission. The average cost of the index admission for these patients was higher than subsequent admissions for MBD or SREs [€4,994; €4,227 and €4,298; respectively].

Another study analysed the theoretical costs of different treatment schemes for advanced or metastatic NSCLC [27]. The authors used the Delphi method of consensus of a group of experts to quantify the use of resources associated with the preparation and administration of anticancer pharmacotherapy and with the management of related adverse events, using 2009 unit costs. The total cost per patient from starting anticancer therapy until death was estimated to be between $€ 11,301$ and $€ 32,754$ depending on the number of treatment lines received. Therapies associated with adverse events increased the total treatment cost.

More specifically, García et al. [28] estimated the treatment costs to the National Health System (NHS) of lung and bladder cancer attributable to work in 2008 at 61.2 million euros and 26.5 million, respectively.

Finally, Corral et al. [29] performed an extensive retrospective analysis based on patient file reviews and evaluated the hospital costs associated with lung cancer, by histology and stage at diagnosis. The direct costs included diagnosis, surgery, chemotherapy, radiotherapy, other inpatient care and costs of continuing care. The study involved lung cancer cases diagnosed in 2008 and costs were assessed in the three years following diagnosis or up to death. The mean cost per patient in NSCLC was €14,818; ranged from €13,218 in Stage III to $€ 16,120$ in Stage II. The main cost components were chemotherapy $(29.5 \%)$ and surgery $(22.8 \%)$. In these patients, advanced disease stages were associated with a decrease in the relative weight of surgical and inpatient care costs but an increase in chemotherapy costs. The cost of the process of diagnosis was $€ 3,040$. In SCLC patients, the mean cost per patient was $€ 15,418$ for limited disease and $€ 12,482$ for extensive disease. The main cost components were chemotherapy (36.1\%) and other inpatient costs $(28.7 \%)$. In these patients, the costs of the diagnosis were $€ 2,747$.

\section{Costs of cervical cancer}

The gynaecological cancer burden in developing countries is huge primarily due to the high incidence. Cervical cancer is the $4^{\text {th }}$ most common cancer among women worldwide, with mortality rates substantially lower than incidence [2]. However, rates vary widely depending on the prevalence of the human papilloma virus (HPV) infection that causes this neoplasm and the access to programmes for the early diagnosis and treatment of precancerous lesions. In Spain, the estimated incidence rate for 2012 was 10.6 per 100,000 women per year 
(2,511 new cases of cervical cancer). Furthermore, cervical cancer is the $2^{\text {nd }}$ most common female cancer and the $3^{\text {rd }}$ leading cause of cancer deaths in women aged 15 to 44 years [2,39].

Three studies assessed direct costs of cervical cancer in Spain [3032], one study assessed indirect costs [16], and one study considered both direct and indirect costs [33].

Gil et al. conducted a retrospective study using hospital discharge data from all hospital admissions in Spain during the four years period (1999-2002) [30]. An average number of 4,151 hospitalizations due to cervical cancer and 2,761 hospitalizations due to carcinoma in situ were reported. The mean costs of a hospitalization by cervical cancer and carcinoma in situ were $€ 3,098$ and $€ 2,192$; respectively. The estimated annual cost of hospitalizations by cervical cancer and carcinoma in situ in Spain was 19 million euros (13 million $€$ and 6 million, respectively).

Oliva et al. [16] estimated the productivity loss caused by mortality and morbidity also in cervical cancer patients. The annual costs estimated for the year 2003 reached $€ 43.4$ million by the traditional $\mathrm{HC}$ approach and $€ 1.1$ million by the $\mathrm{FC}$ approach. Indirect costs by $\mathrm{HC}$ approach were similar for early mortality and permanent disability. By the FC approach in cervical cancer indirect costs are similar in the three situations, temporary disability, permanent disability, and early mortality.

De Juanes et al. [31] performed a retrospective analysis collecting data from clinical records patients hospitalized in the Autonomous Region of Madrid during the 1999 to 2002. They estimate the costs related to hospital treatment for cervical cancer. An average number of 667 hospitalizations per year were reported and the mean cost per patient was estimated in $€ 5,247$.

Another retrospective study of 849 women who had abnormal cervical cytology results in 2010 quantified the cost of the diagnosis and the initial treatment of lesions, according to cytology and histology results [32]. The costs generated according to cytology result were $€ 1,196$ for atypical squamous cells of undetermined significance (ASCUS), $€ 912.43$ for low-grade squamous intraepithelial lesion (LSIL), €1,333 for high-grade squamous intraepithelial lesion (HSIL), and $€ 6,261.30$ for cervical cancer. Analysis by histology grade showed that the cost for women with cervical cancer $(€ 7,041)$ also differed markedly from that for intraepithelial neoplasia (CIN) (€790.10; €1,131 and €1,181 in CIN1, CIN1 and CIN3, respectively).

Finally, García-Garrido et al. [33], assessed the direct and indirect costs of cervical cancer. They included women diagnosed of cervical cancer in 2011 in Cantabria. The annual direct cost of cervical cancer (average 2008-2010) was $€ 567,567$ with a mean number of 91 cases per year, including costs due to burden of disease and screening for cervical cancer. The annual indirect costs due to lost productivity from morbidity or premature death were $€ 386,122$.

\section{Cost of skin cancers}

Non-Melanoma Skin Cancer (NMSC) is the most common type of skin cancer and also the most frequent of all cancers [46]. However, the burden of NMSC remains unclear and it is often not reported to cancer registries, hence accurate incidence rates are difficult to estimate [46]. Although mortality from NMSC is rare in the general population, treatment of NMSC poses a considerable economic impact on the health-care system. In contrast, cutaneous melanoma is less common, with a prevalence of $1.3-2.5 \%$ of all malignant tumours in Spain [47]. However, the mortality associated with this type of tumour is very high.
A total of four studies assessed medical direct costs of skin cancer; two of them reported costs in cutaneous melanoma [36,37] and the other two in NMSC patients [34,35]. Hernández-Martín et al. [34] calculated the cost of the year 2005 per episode in the surgical treatment of NMSC. They found that costs varied substantially, depending on the surgical procedure performed and the related health services requires, with an estimated costs between $€ 273.71$ to $€ 1,129$ per patient/episode. The costs of the surgical-care process of NMSC were also assessed in a retrospective analysis for hospitalized patients from 2006 to 2010 [35]. The mean cost of an inpatient episode was estimated at $€ 2,328$, using activity-based costing (ABC) method. The costs of episodes also varied significantly according to the type of admission, from minor outpatient surgery, the least costly method, followed by major outpatient surgery to inpatient surgery.

Fernández et al. [36], performed a theoretical model to estimate the costs on yearly basis (referred to 2007) of the diagnostic process and treatment in patients with cutaneous melanoma by stages. Thus, they estimated costs in patients with invasive melanoma $<1 \mathrm{~mm}$ thick $(€ 2,066)$, with melanoma $>1 \mathrm{~mm}$ thick and a positive sentinel lymph node $(€ 2,635)$ and with melanoma $>1 \mathrm{~mm}$ thick and negative sentinel lymph node biopsy $(€ 2,774)$. In addition, patients with lymph node metastasis may generate cumulative costs from $€ 7,793$ to $€ 9,082$ depending also on the thickness of melanoma. As there are several possibilities for the treatment and follow-up until the visceral metastases has been identified, the total costs for patients with visceral metastasis must be calculated by adding $€ 1036.58$ to the steps followed in each individual case.

Finally, Mechón et al. [37] assessed only the medical costs of a sentinel lymph node biopsy, based on 2013 unit prices. A mean of 2 nodes were biopsied per patient. The total costs were estimated between $€ 9,486$ and $€ 10,471$, with histopathology accounted for a considerable portion of the cost $(€ 5,769)$.

Our descriptive review identified an additional paper reporting on the costs of soft tissue sarcoma [38]. Barrientos-Ruiz et al. estimated the mean costs of diagnostic and treatment per patient in $14,427.58 €$ (referred to 2009). Interestingly the overall mean cost was lower in those patients referred to a reference centre before the biopsy than in patients referred afterwards $(11,818.67 € v s .16,456.74 €)$.

\section{Discussion}

Cost of illness studies summarizing the economic burden of a particular disease may be helpful in determining appropriate allocation of scarce health-care resources [8-10]. It should be noted that cost of illness studies have a different purpose than health economic evaluations such as cost-effectiveness analysis, which are focused on evaluating the costs and outcomes of two or more clinical interventions. Our study reviewed 27 COI studies; the vast majority conducting cost estimation for colorectal, lung, breast, prostate, cervical, and skin cancers. Probably because of their high incidence and mortality rates, these cancers are the ones with the largest number of published cost studies. In addition, if we look at other contexts such as the US, where cost studies on many types of cancers have been conducted; breast, prostate, colorectal and lung cancers were also those with the highest direct expenditures [48].

One of the most notable findings in this review is that the methodology used to assess the costs varied considerably among the 27 studies examined. Some of these methodological differences that should be considered when evaluating COI studies related to cancer included the study design itself, the criteria for patient inclusion, 
sources of data for estimating the costs, the period over which the costs are calculated, the type of costs considered and approaches used to estimate indirect costs from lost productivity. Therefore, comparing on these results is difficult because significantly different approaches had been adopted to estimate the costs of cancers and the comparison of the results reported in each study is not very useful, since the list of cost components included in the estimation of costs differs from study to study. Prior reviews have also described many of the methodological limitations in economic burden studies observed here [49,50].

Secondly, the review also highlights the scarcity of published studies reporting the costs and lack of standardized data on the burden of the illness in some cancers. Prostate cancer is the third most common cancer in men [2], and only three studies from the last 15 years provide information on its cost in Spain [13-15]. In addition, there is a lack of updated studies, since almost half of the articles were conducted about 10 years ago. Lastly, some studies analysed the healthcare resources and costs of cancer based on consensus opinion of a group of experts or through economic models, and, hence, the results reported are not based on clinical practice $[15,20,21,27,36]$. Consequently, both the variations in methodological considerations and the scarcity of properly designed studies were likely to influence the precision of the estimates and hence the quality of the studies [51].

Only a qualitative synthesis could be conducted in this review due to the scarcity of studies, considerable design differences and heterogeneity of reported outcomes. In Spain, the ranking of cancers according to their economic burden is similar to that in European countries, with the lung, breast and colorectal cancers in the first positions. Overall, the percentage of the total economic cost of cancer in Europe was estimated at 15\% for lung cancer, $12 \%$ for breast cancer, $10 \%$ for colorectal cancer and $7 \%$ for prostate cancer, accounting all of them for $44 \%$ of the total costs [5]. From those studies assessing the direct costs attributable to mean treatment cost, which was by far the largest component of costs in our selected studies, breast cancer costs ranged from $€ 9,838$ to $€ 28,776$ [20]; colorectal costs ranged from $€ 20,478$ to $€ 27,000$ [23,25]; prostate cancer costs ranged from $€ 3,337$ to $€ 6,265[13,14]$; and cervical cancer costs ranged from $€ 2,192$ to $€ 5,247$ $[30,31]$. Only one study reported mean treatment costs in lung cancer patients, with an estimated maximum cost of $€ 16,120$ in stage II patients [29]. Nevertheless, the lifetime costs of patients with advanced lung cancer were found to be much higher than those reported for advanced prostate cancer [15,27]. Supporting these results, hospital burden analysis found that the average cost of index admission for lung cancer patients was higher than costs in breast and prostate cancers [12]. Thus, lung, breast and colorectal cancers were the ones that consume the highest amount of resources in Spain. The high economic weight of lung and colorectal cancers is probably due both to their incidence and mortality rates. Although breast cancer causes fewer deaths, it has a high incidence, similar of lung cancer in men.

Cancer is associated not only to a substantial consumption of health resources, but also to productivity losses and early retirement. Indirect costs, also known as productivity costs, are the costs associated with lost or impaired ability to work due to morbidity or mortality. In Europe, $60 \%$ of the economic burden of cancer was incurred in non-health-care areas, with almost $€ 43$ billion incurred in lost productivity attributable to early death [5]. Nevertheless, only four studies in our review assessed indirect costs. Among those studies that included indirect costs, the costs resulting from temporal disability were also higher in breast and colorectal cancer followed by cervical cancer $[18,24,33]$. Oliva et al. [16] compared in the same study indirect costs in breast cancer and cervical cancer patients. Although there was substantial variation between the methods used to calculate indirect costs, these were much higher for breast cancer than those observed in cervical cancer.

Although the contribution of treatment to the total medical costs has not been assessed in any of the reviewed studies, Arca et al. [26] found that outpatient treatment cost in lung cancer patients was $62 \%$ lower than cost for hospitalization. These results are in line with the rest of Europe, where inpatient care costs accounted for $56 \%$ of cancer-related health-care costs, while drug costs accounted for only $27 \%$ of the total health-care costs [5]. Although costs of cancer vary among studies, as it already mentioned above, direct costs were more substantial for patients with prolonged survival even with metastasis, and the most advanced stages are not those with the highest costs $[13,20,29]$.

Furthermore, the majority of studies underestimated the total costs, since they only gave an estimate of direct costs, but not the indirect and the intangible costs, which are presumed to be significant $[16,18,24,33]$. For example, costs in regard to temporary disability in patients with breast and colorectal cancer reached $€ 14,767,860$ and $€ 4,335,521$; respectively, in one year [17,29]. Only the indirect cost of breast cancer represented the $0.6 \%$ of the total costs in TD spending in 2010 in Spain [17]. Even though the lower incidence and mortality rates of prostate cancer in men, and cervical cancer in women the long duration of the disease make them also an important causes of economic burden in Spanish population.

The findings of this study are limited by having examined only two biomedical databases for studies published in English or Spanish in the last 15 years. It is possible that a broader search with multiple databases and with no language or date restrictions may have uncovered additional COI studies in cancer with different results than those included in this review. However, despite the variation in the costs reported by the analysed studies, this updated literature synthesis demonstrated that cancer represents an important economic burden. Presumably, the major drivers of the rising costs in cancer will be derived from the high costs of novel biological therapies. Although they provide a renewed optimism for cancer care and are extensively used in the clinical setting, these drugs have major research and development costs which make them more expensive therapies if compared to synthetic drugs.

\section{Conclusion}

In general, estimates of disease costs in cancer vary widely across studies in the literature analysed, making it difficult to reach a conclusion or compare the costs. Methodological heterogeneity among studies is probably due to the lack of consensus in terms of cost estimation, availability of data sources and presentation and selection is at the discretion of researchers. Therefore, the definition of standards to conduct health economic studies should be a major concern for the scientific community, and future COI studies would benefit from a common methodology. Due to this heterogeneity no effort has been made to present pooled results from the studies in order to provide average costs for cancer in Spain.

\section{References}

1. http://ec.europa.eu/eurostat/statistics-explained/index.php/Causes_of_death_ statistics

2. Ferlay J, Steliarova-Foucher E, Lortet-Tieulent J, Rosso S, Coebergh JW, et al. (2012) Cancer incidence and mortality patterns in Europe: estimates for 40 countries in 2012. Eur J Cancer 49: 1374-1403.

3. Sanchez MJ, Payer T, De Angelis R, Larranaga N, Capocaccia R, et al. (2010) Cancer incidence and mortality in Spain: estimates and projections for the period 1981-2012. Ann Oncol 21: 30-36. 
4. European Society for Medical Oncology (2012) The burden and cost of cancer. Ann Oncol 18: iii8-iii22.

5. Fernandez R, Leal J, Gray A, Sullivan R (2013) Economic burden of cancer across the European Union: a population-based cost analysis. Lancet Onco 14: $1165-1174$

6. Smith TJ, Hillner BE (2011) Bending the cost curve in cancer care. N Engl J Med 364: 2060-2065.

7. Elkin EB, Bach PB (2010) Cancer's next frontier: addressing high and increasing costs. JAMA 303: 1086-1087.

8. Larg A, Moss JR (2011) Cost-of-illness studies: a guide to critical evaluation Pharmacon Econom 29: 653-671.

9. Akobundu E, Ju J, Blatt L, Mullins CD (2006) Cost-of-illness studies: a review of current methods. Pharmaco Economics 24: 869-890.

10. Kriza C, Emmert M, Wahlster P, Niederlander C, Kolominsky-Rabas P (2013) Cost of illness in colorectal cancer: an international review. Pharmacoeconomics 31: $577-588$

11. Brown ML, Lipscomb J, Snyder C (2001) The burden of illness of cancer: economic cost and quality of life. Annu Rev Public Health 22: 91-113.

12. Pockett RD, Castellano D, McEwan P, Oglesby A, Barber BL, et al. (2010) The hospital burden of disease associated with bone metastases and skeletalrelated events in patients with breast cancer, lung cancer, or prostate cancer in Spain. Eur J Cancer Care 19: 755-760.

13. Fourcade RO, Benedict A, Black LK, Stokes ME, Alcaraz A, et al. (2010) Treatment costs of prostate cancer in the first year after diagnosis: a shortterm cost of illness study for France, Germany, Italy, Spain and the UK. BJU Int 105: 49-56.

14. Becerra V, Cots F, Guedea F, Pera J, Boladeras A, et al. (2011) Cost comparison of three treatments for localized prostate cancer in Spain: radical prostatectomy, prostate brachytherapy and external 3D conformal radiotherapy. Gac Sanit 25: 35-43.

15. Hart WM, Nazir J, Baskin-Bey E (2014) An incidence model of the cost of advanced prostate cancer in Spain. J Med Econ 17: 125-131.

16. Oliva J, Lobo F, Lopez-Bastida J, Zozaya N, Romay R (2005) Indirect costs of cervical and breast cancers in Spain. Eur J Health Econ 6: 309-313.

17. Grupo Espanol Para el Desarrollo de la Farmacia Oncologica (GEDEFO) (2008) Transversal study of breast cancer treatment in Spain. Farmacia Hospitalaria 32: 139-147.

18. Herrero MT, García MJ, Iñiguez MV, García LM, Jiménez E, et al. (2010) Breast cancer in Spain. Economic cost approach to temporary disability in 2010. Gaceta Mexicana de Oncología 11: 351-357.

19. Angulo-Pueyo E, Ridao-López M, Martínez-Lizaga N, García-Anmesto S Bernal-Delgado E (2014) Variability and opportunity costs among the surgical alternatives for breast cancer. Gac Sanit 28: 209-214.

20. Arrospide A, Soto-Gordoa M, Acaiturri T, López-Vivanco G, Abecia LC, et al. (2015) Cost of breast cancer treatment by clinical stage in the Basque Country, Spain. Rev Esp Salud Publica 89: 93-97.

21. Jodar-Sanchez F, Jose Lopez L, Parra C, Leal S, dos Santos MA, et al. (2014) Healthcare costs associated with adjuvant radiation therapy for early breast cancer. Revista de Senología y Patología Mamaria 27: 68-73.

22. Novoa AM, Cots F, Macià F, Castells $X$ (2008) Cost of the diagnostic process in colorectal cancer. Medicina Clínica 130: 116-117.

23. Cots F, Novoa A, Macià F, Gallén M, Mateu X, et al. (2007) Cost hospitalari del tractament del Càncer colorrectal. A Estudis d'Economia de la Salut. Barcelona: Direcció General de Planificació i Avaluació. Departament de Salut.

24. Vicente-Herrero MT, Terradillos-García MJ, Ramírez-Iñiguez de la Torre MV, Capdevila-García LM, López-González AA (2013) Colorectal cancer in Spain: temporary disability and preventive occupational strategies. Revista de Gastroenterología de México 78: 75-81.

25. Torres C, Oyagüez I, Lozano V, Pericay C, Pàmpols M, et al. (2014) Análisis de patrones de tratamiento y coste farmacológico en pacientes con cáncer colorrectal metastásico en un hospital general. PharmacoEconomics Spanish Research Articles 11: 85-96.

26. Arca JA, Ramos MA, de la Infanta RG, Lopez CP, Perez LG, et al. (2006) Lung cancer diagnosis: hospitalization costs. Arch Bronconeumol 42: 569-574.

27. Isla D, González-Rojas N, Nieves D, Brosa M, Finnern HW (2011) Treatment patterns, use of resources, and costs of advanced non-small-cell lung cancer patients in Spain: results from a Delphi panel. Clin Transl Oncol 13: 460-471.
28. Garcia M, Urbanos R, Castaneda R, Lopez P (2012) Direct Health Care Costs of Lung and Bladder Cancer Attributable to Work. Spain, 2008. Rev Esp Salud Publica 86: 127-138.

29. Corral J, Alfons J, Cots F, Pareja L, Solà J, et al. (2015) Estimation of lung cancer diagnosis and treatment costs based on a patient-level analysis in Catalonia (Spain). BMC Health Services Research 15: 70.

30. Gil A, San-Martín M, Gil R, Hernández V, Ribes J, et al. (2007) Burden of hospital admissions for cervical cancer in Spain during 1999-2002. Hum Vaccin 3: $276-280$.

31. De Juanes JR, Arrazola P, García de Codes A, Gil R, San-Martíni M, et al. (2010) Hospital admissions for cervical cancer in the autonomous Region of Madrid, 1999-2002. Progresos de Obstetricia y Ginecologia 53: 297-302.

32. Blade A, Cararach M, Castro M, Catalá-López F, Pérez-Escolano I, et al. (2010) Clinical management of abnormal cytology test results and costs associated with the prevention of cervical cancer in Spain. J Low Genit Tract Dis 14: 311-318.

33. Garrido A, Rodríguez J, González E, Barrón M (2014) [Coverage and costs of opportunistic screening for cervical cancer in Cantabria (Spain)]. Gac Sanit 28: $14-19$

34. Hernandez-Martin A, Nunez Reiz A, Saiz Martinez M, Juncosa J (2006) Cost per episode of care in the surgical treatment of skin cancer. Gac Sanit 20: 273-239.

35. Aguilar-Bernier M, González-Carrascosa M, Padilla-España L, Rivas-Ruiz F, Jiménez-Puente A, et al. (2010) Five-year economic evaluation of nonmelanoma skin cancer surgery at the Costa del Sol Hospital (2006-2010). J Eur Acad Dermatol Venereol 28: 320-326.

36. Fernández FM, Ortega S, Villalonga JJ (2009) Descriptive study of the costs of diagnosis and treatment of cutaneous melanoma]. Actas Dermosifiliogr 100: 785-791.

37. Menchón T, Pedreño P, Escribano J, Vélez R, Barba E (2015) Cost analysis of sentinel lymph node biopsy in melanoma. Actas Dermosifiliogr. 106: 201-207.

38. Ruiz I, Serrano-Montilla J, Ortiz-Cruz EJ (2012) Cost analysis of the diagnosis and treatment of soft tissue sarcomas in reference centres. Rev Esp Cir Ortop Traumatol 56: 374-377.

39. Ferlay J, Soerjomataram I, Ervik M, Dikshit R, Eser S, et al. (2013) GLOBOCAN 2012 v1 0, Cancer incidence and mortality worldwide: IARC CancerBase No. 11. Lyon, France: International Agency for Research on Cancer.

40. Eastham JA, Riedel E, Scardino PT, Shike M, Fleisher M, et al. (2003) Polyp Prevention Trial Study Group Variation of serum prostate-specific antigen levels: an evaluation of year-to-year fluctuations. JAMA 289: 2695-2700.

41. Penson DF, Rossignol M, Sartor AO, Scardino PT, Abenhaim LL (2008) Prostate cancer: epidemiology and health-related quality of life. Urology 72: S3-S11.

42. Mariotto AB, Yabroff KR, Shao Y, Feuer EJ, Brown ML (2011) Projections of the cost of cancer care in the United States: 2010-2020. J Natl Cancer Inst 103: $117-128$

43. Shapiro D, Tareen B (2012) Current and emerging treatments in the management of castration-resistant prostate cancer. Expert Rev Anticancer Ther 12: 951-964.

44. Redaelli A, Cranor CW, Okano GJ, Reese PR (2003) Screening, prevention and socioeconomic costs associated with the treatment of colorectal cancer. Pharmacoeconomics 21: 1213-1238.

45. Bareschino MA, Schettino C, Rossi A, Maione P, Sacco PC, et al. (2011) Treatment of advanced non-small cell lung cancer. J Thorac Dis 3: 122-133.

46. Lomas A, Leonardi-Bee J, Bath-Hextall F (2012) A systematic review of worldwide incidence of nonmelanoma skin cancer. Br J Dermatol 166: 1069-1080.

47. Sáenz S, Conejo-Mir J, Cayuela A (2005) Epidemiología del melanoma en España. Actas Dermosifiliogr 96: 411-418.

48. Yabroff KR, Warren JL, Brown ML (2007) Costs of cancer care in the USA: a descriptive review. Nat Clin Pract Oncol 4: 643-656.

49. http://meps.ahrq.gov/mepsweb

50. Yabroff KR, Borowski L, Lipscomb J (2013) Economic Studies in Colorecta Cancer: Challenges in Measuring and Comparing Costs. J Natl Cancer Inst Monogra 46: 62-78.

51. Molinier L, Bauvin E, Combescure C, Castelli C, Rebillard X, et al. (2008) Methodological considerations in cost of prostate cancer studies: a systematic review. Value Health 11: 878-885. 